\title{
PEMBATASAN TERHADAP PERSAINGAN UNTUK MEMBENTUK \\ PASAR DALAM KASUS STANDARD ESSENTIAL PATENT (SEP) \\ (PERBANDINGAN HUKUM PERSAINGAN USAHA DI INDONESIA \\ DAN UNI EROPA)
}

\author{
Sih Yuliana Wahyuningtyas \\ Fakultas Hukum Unika Atma Jaya \\ Email: yuliana.siswartono@atmajaya.ac.id
}

\begin{abstract}
The role of patents is complex when dealing with the problem of technological interoperability in cases where patented technology becomes standard. In such cases, a balance is needed between the protection of the interests of the inventor, i.e. the standard essential patent (SEP) holder, and of users who need the technology to enter the market. There is a susceptibility to restrictions on competition to create markets (competition for the market). Market dominance can be created by the adoption of SEP holder technology as a standard and hence, a key for other business actors to enter the market. With the potential for the formation of a dominant position in the relevant market, the competition law intervention is required when patent abuse occurs, as it appears typical in the pharmaceutical and information technology industries. The normative research examines how competition law in the European Union deals with SEP cases in comparison to Indonesian competition law.
\end{abstract}

Key words: restrictions to competition, standard essential patent (SEP), abuse of dominant position

\begin{abstract}
Abstrak
Peran paten menjadi kompleks ketika berhadapan dengan persoalan interoperabilitas teknologi ketika teknologi yang dipatenkan menjadi standard. Dalam kasus-kasus demikian, diperlukan adanya perimbangan antara perlindungan atas kepentingan inventor yang mememegang standard essential patent (SEP) dengan kepentingan pengguna yang membutuhkan teknologi tersebut untuk masuk ke dalam pasar. Dalam hal ini, rentan terjadi pembatasan atas persaingan untuk membentuk pasar (competition for the market). Dominasi pasar dapat tercipta dengan diterimanya teknologi pemegang SEP sebagai standard dan kunci bagi pelaku usaha lain untuk masuk ke dalam pasar. Dengan potensi terbentuknya posisi dominan dalam pasar yang relevan bagi pemegang SEP tersebut, ruang analisis menjadi terbuka untuk hukum persaingan usaha ketika terjadi penyalahgunaan paten sebagaimana tampak khas dalam industri farmasi dan teknologi informasi. Penelitian yang menggunakan metode penelitian yuridis normative ini menyajikan perkembangan yang terjadi di Uni Eropa. Permasalahan yang menjadi fokus dalam paper ini adalah analisis hukum persaingan usaha di Uni Eropa dalam kasus penyalahgunaan SEP dan perbandingannya dengan hukum persaingan Indonesia.
\end{abstract}

Kata kunci: pembatasan terhadap persaingan, standar essential patent (SEP), penyalahgunaan posisi dominan 


\section{Pendahuluan}

Perlindungan paten memainkan peran penting untuk memberikan insentif bagi dunia industri untuk berinovasi dengan memastikan diberikannya kontra prestasi yang sepatutnya bagi inventor dari pihak lain yang menggunakan teknologi inventor. Dalam era ketika standardisasi menjadi semakin penting antara lain untuk memastikan interoperabilitas teknologi, perimbangan antara terlindunginya kepentingan pemegang standard essential patent (SEP) dengan pengguna yang membutuhkan teknologi tersebut untuk masuk ke dalam pasar menjadi penting.

Sebagaimana dijelaskan oleh Jorge Contreras, ${ }^{1}$ pentingnya standard dalam dunia industri dapat dilihat dari semakin meluasnya penggunaan standard untuk memungkinkan terjadinya interoperabilitas teknologi, seperti yang terjadi dalam industri informasi dan teknologi. The United States Department of Justice and Federal Trade (selanjutnya disingkat US DOJ \& FTC) secara tepat menyebutkan beberapa hal positif yang dibawa oleh standard dalam Laporan tentang 'Antitrust Enforcement and Intellectual Progperty Rights: Promoting Innovation and Competition' tahun 2007. Dalam Laporan tersebut dikemukakan bahwa "Standards can make products less costly for firms to produce and more valuable to consumers. They can increase innovation, efficiency, and consumer choice; foster public health and safety; and serve as a 'fundamental building block for international trade. ${ }^{2}$

Penggunaan standard dapat menghasilkan biaya produksi yang rendah dapat berimplikasi pada harga produk yang rendah pula. Selain itu, konsumen dapat menikmati pula kualitas produk yang lebih baik. Secara keseluruhan, industri dapat memperoleh keuntungan dari penggunaan standard dalam beberapa bentuk: (1) inovasi-baik dari insentif untuk berinovasi bagi produsen agar teknologinya dapat diterima sebagai standar, maupun pengakuan secara ekonomis dan yuridis atas inovasi yang dilakukan - ; (2) efisiensi - karena hanya teknologi yang efisien yang dapat diterima sebagai standard; (3) tersedianya pilihan bagi konsumen di pasar - dorongan untuk berkompetisi untuk menghasilkan teknologi yang nantinya dapat diakui sebagai standard memacu pelaku pasar untuk berinovasi dan menghasilkan beragam produk, sehingga pasar mampu menawarkan beragam pilihan bagi konsumen.

Standard dapat terbentuk secara sukarela oleh pasar. Katz dan Saphiro mengemukakan bahwa "In markets with network effects, there is natural tendency toward de facto

1 Jorge L. Contreras, "Fixing FRAND: A Pseudo-Pool Approach to Standard-Based Patent Licensing", Antitrust Law Journal Vol. 49, (2013): 47.

2 U.S. Department of Justice and Federal Trade Commission (selanjutnya disebut US DOJ \& FTC), 'Antitrust Enforcement and Intellectual Progperty Rights: Promoting Innovation and Competition', hlm. 6, http://www. $\mathrm{ftc}$.gov/reports/innovation/P040101PromotingInnovationandCompetitionrpt0704.pdf, diakses 3 September 2018 . 
standardization, which means everyone using the same system." 3 Standardisasi de facto terjadi manakala pengguna teknologi secara sukarela dan unilateral menggunakan suatu system atau teknologi yang sama. Dalam hal ini tidak terdapat koordinasi oleh pelaku pasar agar teknologi tersebut digunakan oleh semua orang.

Selain itu, standard dapat pula dibuat dengan membentuk suatu oraganisasi untuk mengkoordinasikan pembentukan standard yang melibatkan stake holder yang berkepentingan. Contreras menjelaskan bahwa "Most of the thousands of technical standards currently deployed throughout the world were developed collaboratively by market participants in voluntary standardsdevelopment organizations (SDOs)."4 Standards-Development Organization (selanjutnya disingkat SDO) atau StandardsSetting Organization (selanjutnya disingkat SSO) memiliki peran penting dalam pembentukan standard. Salah satu peran tersebut adalah membuat kebijakan bagaimana proses untuk pengakuan atau penerimaan suatu teknologi menjadi standard.

Thomas Cotter mengemukakan bahwa SSOs sering mensyaratkan para anggotanya untuk menyampaikan sejumlah informasi yang esensial sebelum suatu teknologi dapat dipertimbangkan dan diterima sebagai standard. Informasi penting tersebut antara lain: (1) paten atau pending patent yang mungkin relevan untuk diterimanya suatu teknologi yang sedang dipertimbangkan sebagai standard; (2) menyatakan paten manakah dari teknologinya yang bersifat esensial untuk teknologi yang memiliki prospek untuk menjadi standar; dan (3) menyatakan kesediaannya untuk melisensikan SEPnya tersebut berdasarkan prinsip Fair, Reasonable, and Non-Discriminatory (selanjutnya disingkat FRAND). ${ }^{5}$ Hal terakhir ini sering disebut juga dengan istilah komitmen FRAND (FRAND commitment).

Kebijakan SSO mengenai IPR dapat beraneka ragam. Cotter menyebutkan sejumlah contoh kebijakan SSO yang paling relevan dengan kasus perang paten antar mobile devices yang sering terjadi. Beberapa yang disebutkannya adalah kebijakan dari the European Telecommunications Standards Institute (ETSI), the Institute of Electrical and Electronics Engineers (IEEE), and the common policy of the International Telecommunication Union (ITU), International Organization for Standardization (ISO), and the International Electrotechnical Commission (IEC). ${ }^{6}$

Namun demikian, sebagaimana dikemukakan oleh U.S. DOJ \& FTC, terdapat

3 Michael L. Katz and Carl Saphiro, 'Systems Competition and Network Effects', Journal of Economic Perspectives Vol. 8, No. 2 (Spring 1994): 105.

4 Jorge L. Contreras, loc.cit.

5 Thomas F. Cotter, "The Comparative Law and Economics of Standard-Essential Patents and FRAND Royalties”, Texas Intellectual Property Law Journal Vol. 22, (2014): 311.

6 Ibid.: 314. 
pula sisi negative atau potensi persoalan hukum persaingan dalam hal penyusunan standard secara kolaboratif. Dalam Laporan yang sama, disebutkan bahwa "collaboratively set standards can reduce competition and consumer choice and have the potential to prescribe the direction in which a market will develop, courts have been sensitive to antitrust issues that may arise in the context of collaboratively set standards." 7

Suatu standard yang dibentuk secara kolaboratif, misalnya melalui SSO, dapat mengurangi persaingan. Anggota SSO terdiri pula atas pesaing, dalam hal ini mereka bersaing untuk membuat suatu teknologi dan dengan demikian, suatu pasar yang baru. Melalui SSO, mereka dapat membuat kesepakatan untuk menentukan teknologi yang paling menguntungkan bagi mereka dan berimbas pada menjadi terbatasnya pilihan konsumen. Perlu diingat, bahwa dengan adanya standard, maka pemenang persaingan tersebut akan mendapatkan semua keuntungan dari pasar (winner takes all).

Lebih lanjut, Rolf H. Weber menjelaskan sejumlah sisi negatif standard. Pertamatama, standard pada dasarnya mengandung penguragan keragaman produk dan hal ini dapat mengurangi motivasi dan upaya pelaku pasar untuk bersaing. Berikutnya, dapat terjadi hilangnya persaingan antara format teknologi alternatif dan teknologi substitusi. Dalam hal standard dimandatkan oleh regulasi, dapat terjadi standardisasi yang berlebih-lebihan, karena regulator berusaha untuk membuat pengaturan yang terlalu rigid. Persoalan hukum persaingan dapat timbul jika penggunaan suatu standard berdampak pada ekspoitasi kekuatan pasar misalnya dalam bentuk penyalahgunaan posisi dominan. ${ }^{8}$

Dapat terjadi bahwa perlindungan paten untuk SEP disalahgunakan oleh pemegangnya misalnya semata-mata untuk mendapatkan keuntungan finansial dengan cara patent hold up. Dengan cara ini, perusahaan membuat teknologi dan mematenkannya kemudian paten tersebut melalui suatu proses pembuatan standard diadopsi menjadi SEP. Namun demikian, pemegang SEP sendiri tidak menggunakan teknologi yang sudah menjadi standard tersebut dan sebaliknya, mencari keuntungan dengan menarik royalti tinggi dari para penggunanya.

Cara lain misalnya pemegang paten dalam kasus yang serupa juga mencari keuntungan dengan meminta royalti tinggi dari para penggunanya, namun dia sendiri masih menggunakan teknologi yang menjadi standard tersebut. Ada pula kasus, inventor dalam proses pembuatan standard sengaja tidak menyampaikan strategi dan rencana patennya. Ketika mengetahui bahwa teknologinya akan diadopsi menjadi standard, kemudian menyesuaikan permohonan

7 US DOJ \& FTC, Ibid., hlm. 34.

8 Rolf H. Weber, “Competition Lawversus FRAND Terms in IT Markets", World Competition 34, no. 1 (2011): 54. 
patennya sehingga kemudian teknologi tersebut dipatenkan. Ketidakjujuran ini dapat merugikan para pengguna teknologi tersebut, karena jika mereka mengetahui adanya rencana paten tersebut, dapat saja mereka memilih untuk mengadopsi teknologi lain yang mungkin saja lebih murah.

Hukum persaingan usaha dapat menjadi berperan ketika terjadi penyalahgunaan posisi dominan yang diraih pemegang paten karena teknologinya menjadi standard dan menjadi kunci masuk bagi pelaku usaha lain ke dalam pasar sebagaimana tampak khas dalam industri farmasi dan teknologi informasi. Persoalannya adalah bagaimana peran itu dimainkan?

Dalam penelitian dan pembahasan, paper ini memusatkan perhatiannya pada dua permasalahan. Pertama, bagaimana penyalahgunaan SEP dapat menjadi persoalan hukum persaingan usaha di Uni Eropa? Kedua, bagaimana penyalahgunaan SEP di Uni Eropa dalam terjadi dalam kasus-kasus yang pernah ada? Ketiga, bagaimana analisis kasus SEP dalam hukum persaingan usaha di Indonesia?

\section{A. SEP dan Relevansi Hukum Persaingan Usaha di Uni Eropa}

\section{Standardisasi dan Persaingan untuk Membentuk Pasar}

Dari sudut pandang hukum persaingan usaha, proses untuk mengembangkan standar adalah sama dengan proses untuk menciptakan pasar. Dengan demikian, sampai standar tersebut dibuat atau diadopsi, sebenarnya belum ada pasar untuk teknologi yang sedang dikembangkan atau dievaluasi. Perusahaan bersaing agar teknologi mereka diadopsi dalam standar.

Namun demikian, persaingan tersebut lebih merupakan persaingan dalam berinovasi (competition in innovation) atau persaingan untuk membentuk pasar (competition for a market) dan bukan persaingan di dalam pasar (competition in the market). ${ }^{9}$ Hukum persaingan usaha Uni Eropa telah memuat pengaturan mengenai perjanjian untuk menetapkan standar di dalam Pedoman Horizontal Uni Eropa (EC Horizontal Guidelines ${ }^{10}$ yang mencerminkan bagaimana persaingan dalam inovasi dan persaingan untuk membentuk pasar dimasukkan dalam analisis hukum persaingan usaha. ${ }^{11}$

Hukum persaingan uasha Uni Eropa dalam larangan kartel(Pasal 101 TFEU) menyediakan landasan penting untuk memperhitungkan disruptive innovation di berbagai sektor di bawah EU Horizontal Gudielines, R \& D BER, Technology Transfer Guidelines (TT Guidelines) $)^{12}$, dan Technology Transfer Block Exemption Regulation (TTBER) ${ }^{13} . E U$ Horizontal Gudielines dan R \& D BER adalah

9 Josef Drexl, "Anti-Competitive Stumbling Stones on the Way to A Cleaner World: Protecting Competition in Innovation Without A Market", Journal of Competition Law \& Economics, Vol. 8, N.o. 3, (2012): 543.

10 Communication from the Commission (2011/C 11/01) of 14 January 2011 on 'Guidelines on the applicability of Article 101 of the Treaty on the Functioning of the European Union to horizontal co-operation agreements' [2011] OJ 2011 C11/1, selanjutnya disebut EU Horizontal Guidelines.

11 Ibid., par. 257.

12 Communication from the Commission (2014/C 89/03) of 28 March 2014 on 'Guidelines on the application of Article 101 of the Treaty on the Functioning of the European Union to technology transfer agreements' [2014] OJ 2014 C89/3, selanjutnya disebut EU TT Guidelines.

13 Commission Regulation (EU) No 316/2014 of 21 March 2014 on the application of Article 101(3) of the Treaty on the Functioning of the European Union to categories of technology transfer agreements Text with EEA relevance' [2014] OJ 2014 L93/17, selanjutnya disebut TTBER. 
dua instrumen yang menentukan, karena fase ketika pelaku usaha terlibat dalam kegiatan $\mathrm{R}$ \& D sangat penting untuk proses menciptakan produk baru atau teknologi. Dengan demikian, sangat penting bahwa dalam fase ini hukum persaingan usaha telah siap dengan instrument yang cukup untuk menilai perjanjian di luar pasar yang sudah ada dalam kasus persaingan usaha dalam inovasi.

Dalam hal ini, bagian dari EU Horizontal Gudielines sehubungan dengan standarisasi menunjukkan pendekatan ke depan untuk mengidentifikasi dalam tahap awal, proses pengaturan standar yang dapat membatasi persaingan terutama yang mencegah teknologi yang inovatif. Pada tahap berikutnya, Pedoman TT dan TTBER memperhitungkan disruptive innovation untuk memastikan bahwa perjanjian untuk menggunakan teknologi berlisensi tidak akan menghalangi munculnya produk atau teknologi baru.

Dalam kasus X/Open Group, keputusan Komisi Persaingan Usaha Uni Eropa menyatakan pandangan bahwa partisipasi dalam proses pengaturan standar harus memungkinkan semua pesaing untuk mengambil bagian dalam proses untuk memilih dan membuat standar, karena mengecualikan pelaku usaha tertentu dapat meningkatkan risiko untuk menimbulkan efek yang membatasi persaingan.

Dalam kasus tersebut Komisi Persaingan Usaha Uni Eropa mempertimbangkan bahwa dalam kelompok penyusuna standard
(Standard Setting Organization, SSO), mereka yang bukan anggota (dilawankan dengan mereka yang menjadi anggota) tidak dapat mempengaruhi hasil kerja SSO dan tidak dapat memperoleh pengetahuan dan pemahaman teknis yang berkaitan dengan hasil proses standardisasi yang mungkin diperoleh oleh para anggota SSO. Selain itu, mereka yang tidak menjadi anggota SSO tidak dapat menerapkan standar sebelum dipublikasikan.

Sementara itu, para anggota SSO dimungkinkan untuk mengimplementasikan standar sebelum publikasi karena pengetahuan lebih awal yang telah dimilikinya mengenai keputusan final SSO dan pengetahuan mengenai arah yang akan dicapai dalam proses standardisasi tersebut. Dalam suatu industri ketika lead time dapat menjadi faktor yang sangat penting, keanggotaan kelompok dapat sehingga memberi keuntungan kompetitif bagi para anggota SSO. ${ }^{14}$

\section{EC Horizontal}

Guidelines

mengkategorikan tiga saluran yang berbeda mengenai cara pengaturan standar yang dapat menimbulkan efek membatasi persaingan, yaitu: (1) pengurangan persaingan harga, (2) pencegahan teknologi inovatif dan (3) pengecualian atau diskriminasi terhadap perusahaan tertentu dengan pencegahan akses yang efektif dengan menggunakan standar. Pencegahan teknologi inovatif dapat terjadi ketika standar membutuhkan spesifikasi teknis yang rinci untuk produk atau jasa dan dengan demikian membatasi pengembangan teknis dan inovasi. 
Standardisasi dapat mengakibatkan, lockin' karena biaya yang hangus selama proses pembuatan standar dan setelah pelaksanaan standar. Hal ini menciptakan switching cost yang tinggi untuk pengguna standar, jika di kemudian hari dibuat teknologi baru yang sebenarnya bisa lebih efisien daripada standar yang ada. Dengan demikian, lock-in mengakibatkan hambatan masuk untuk teknologi baru. Lebih lanjut, inovasi dapat dibatasi, ketika proses penyusunan standar mengecualikan pelaku usaha tertentu. ${ }^{15}$

EC Horizontal Guidelines mengenali pembagian peran dan kepentingan antara kekayaan intelektual (IP) dan hukum persaingan usaha dalam mempromosikan inovasi. Sebagai contoh adalah dengan memungkinkan kembalinya modal investasi, ${ }^{16}$ dan kesejahteraan konsumen, dengan menekankanperanHKIuntukmempromosikan persaingan dinamis (dynamic competition) dengan cara memberikan insentif bagi pelaku usaha untuk mengembangkan produk dan proses yang baru atau lebih baik. ${ }^{17}$

Namun demikian, Guidelines tersebut juga mengakui dampak anti-persaingan standardisasi dalam kasus ketika pelaku usaha tertentu dicegah untuk mendapatkan akses HKI yang esensial untuk menerapkan standar. Oleh karena itu, diperlukan perjanjian untuk memastikan pengungkapan HKI yang relevan dan potensial untuk menjadi esensial bagi semua peserta pembentukan standar dan pada langkah berikutnya, menjamin penyediaan akses yang efektif untuk menggunakan standar. ${ }^{18}$

\section{Perjanjian Lisensi}

Intervensi hukum persaingan usaha dalam kasus-kasus yang menyangkut hak kekayaan intelektual (selanjutnya disingkat HKI), khususnya dalam hal penggunaan teknologi yang dipatenkan, European Commission telah mengadopsi serangkaian aturan persaingan usaha untuk mengevaluasi perjanjianperjanjian mengenai transfer teknologi. Serangkaian aturan persaingan usaha tersebut dimuat dalam Technology Transfer Block Exemption Regulation (Regulasi mengenai Pengecualian dalam Transfer Technology, selanjutnya disebut TTBER) berikut pedomannya, Technology Transfer Guidelines (TT Guidelines), yang mulai berlaku 1 Mei 2014.

Perjanjian-perjanjian transfer teknologi yang tunduk pada evaluasi berdasarkan TTBER tersebut adalah perjanjian yang memuat ijin lisensi bagi licensee untuk mengeksploitasi paten, know-how, atau perangkat lunak untuk produksi barang dan jasa. Dalam TTBER tersebut telah diintegrasikan analisis hukum persaingan

15 EU Horizontal Guidelines, op.cit., par. 266; X/Open Group, op.cit., par. 32.

16 European Commission, "Patents and Standards: A Modern Framework for IP-Base Standardization" (Final Report, 25 March 2014), 27 diakses 6 Juli $2018<$ http://ec.europa.eu/DocsRoom/documents/4843/ attachments/1/translations/en/renditions/pdf $>$.

17 Pandangan yang sama ditemukan dalam TT Guidelines, op.cit., par. 7.

18 EU Horizontal Guidelines, op.cit., par. 268. 
usaha untuk kasus-kasus yang menyangkut disruptive innovation, yang lazimnya menjadi persoalan dalam kasus munculnya teknologi baru yang berarti lahirnya pasar yang baru yang tidak dapat diidentifikasi sebelumnya.

TTBER mempertimbangkan dampak perjanjian lisensi terhadap persaingan dalam berinovasi ketika menghapuskan klausula exclusive grant back dari pengecualian terhadap penerapan Pasal 101 (1) TFEU. ${ }^{19}$ Klausula exclusive grant back merujuk kepada kesepakatan yang berisi lisensi eksklusif kembali ke pemberi lisensi dari perbaikan lisensi bersangkutan. ${ }^{20}$

Pedoman TT menjelaskan alasan di balik penghapusan dari pengecualian tersebut, yaitu bahwa semakin kuat posisi pemberi lisensi di pasar, semakin besar kemungkinannya bahwa klausula exclusive grant back akan memiliki dampak membatasi persaingan. Sebaliknya klausula non-exclusive grant back tetap mendapatkan pengecualian di bawah TTBER safe harbour.

TTBER juga mengakui potensi dampak negative cross licensing terhadap persaingan dalam inovasi, ketika dikombinasikan dengan kewajiban untuk masing-masing pihak untuk menginformasikan satu sama lain tentang pengembangan teknologi yang dibuat. Potensi dampak negatif tersebut dimungkinkan karena mereka dapat menghalangi pihak lawannya untuk memenangkan persaingan, kecuali tujuan lisensi adalah untuk memungkinkan para pihak untuk mengembangkan teknologi mereka sendiri dan tidak mengarah pada penggunaan solusi teknis yang sama. ${ }^{21}$

Klausula non-challenge dalam kesepakatan mengenai penyelesaian sengketa juga dihapus dari pengecualian dalam TTBER. Menurut Pedoman TT, pembatasan kebebasan untuk menggugat HKI dapat membatasi persaingan dan oleh karena itu klausula seperti itu harus dianalisis lebih lanjut. Klausula non-challenge dapat dikualifikasikan sebagai pelanggaran atas larangan kartel dalam Pasal 101 (1) TFEU, misalnya ketika HKI telah diberikan berdasarkan 'informasi yang keliru atau menyesatkan'. ${ }^{22}$

Namun demikian, meskipun masuk akal bahwa pemberi lisensi tidak dapat dipaksa untuk mempertahankan kesepakatannya dengan pesaingnya, misalnya ketika pemegang lisensi menggugat keabsahan teknologi yang dilisensikan, menghapus klausula non-challenge dari pengecualian terhadap penerapan Pasal 101 (1) TFEU dapat membuat perusahaan enggan untuk melisensikan teknologinya dan dengan demikian juga mengurangi potensi inovasi yang dapat timbul dari transfer teknologi.

Meskipun persaingan dalam inovasi telah diperhitungkan untuk analisis perjanjian seperti yang dijelaskan di atas, TTBER safe harbor tetap tunduk pada kriteria ambang 
batas pangsa pasar: (1) untuk perjanjian lisensi antarpesaing, pangsa pasar gabungan masingmasing pihak tidak boleh melebihi $20 \%,{ }^{23}$ dan (2) untuk perjanjian lisensi antarpelaku usaha bukan pesaing, pangsa pasar masingmasing pihak tidak boleh melebihi $30 \%{ }^{24}$ Namun demikan, berada di luar safe harbor berdasarkan perhitungan ambang batas pangsa pasar tidak berarti bahwa perjanjian secara otomatis merupakan pelanggaran atas larangan dalam Pasal 101 (1) TFEU dan tidak pula berarti tidak memenuhi persyaratan Pasal 101 (3) TFEU. Sebaliknya, analisis secara kasuistis tetap diperlukan. ${ }^{25}$

Dampak negatif dari perjanjian lisensi yang restriktif telah diantisipasi dalam Pedoman TT berkaitan dengan dampak dari perjanjian terhadap persaingan intertechnology, yaitu persaingan antarpelaku usaha yang melisensikan atau memproduksi atas dasar teknologi yang bersubstitusi. ${ }^{296}$ Dengan perjanjian lisensi yang restriktif semacam itu, dapat dimuat pengaturan mengenai pengembangan teknologi berlisensi di masa depan.

Sebagai contoh, ketika perjanjian lisensi membebankan kewajiban timbal balik kepada para pihak untuk mengalihkan teknologi mereka yang saling bersaing dan saling berbagi hasil pengembangan teknologi masing-masing di masa depan. Di samping itu, dapat dimuat pengaturan yang mencegah salah satu dari mereka untuk memenangkan persaingan teknologi dari yang lain. Menurut Pedoman TT, perjanjian semacam itu dapat membatasi persaingan dalam berinovasi. ${ }^{27}$

\section{Komitmen FRAND (Fair, Reasonable, and Non-}

\section{Discriminatory) dalam Perjanjian}

\section{Lisensi}

Untuk menghindarkan perjanjian lisensi yang dibuat dengan menyalahgunakan paten untuk menguasai pasar antara lain dengan tingkat royalti yang berlebih-lebihan, komitmen FRAND (fair, reasonable, and non-discriminatory) sering diacu sebagai dasar untuk pemebuatan perjanjian lisensi.

Herbert Hovenkamp mendefinisikan komitmen FRAND sebagai "a firm's commitment to make its technology available at a "fair, reasonable and nondiscriminatory royalty" if it is adopted as the standard." 28 Lebih lanjut dijelaskannya bahwa di Amerika Serikat, pada awalnya terminologi yang digunakan adalah "RAND“ dan bukan

23 TTBER, op.cit., Article 3(1).

24 Ibid., Article 3(2).

25 TT Guidelines, op.cit., par. 79.

26 Ibid., par 170, dibedakan dari intra-technology competition, yaitu 'competition between undertakings that produce on the basis of the same technology' (TT Guidelines, par. 173).

27 Ibid., par. 170 and 241; lihat juga David Encaoua \& Abraham Hollander, "Competition Policy and Innovation", Oxford Review of Economic Policy Vol. 18, No. 1 (2002): 75.

28 Herbert J. Hovenkamp, "Competition in Information Technologies: Standard-Essential Patents, Non-Practicing Entities and FRAND Bidding", University of Iowa Legal Studies Research Paper No. 12-32. (October 3, 2012): 7. 
"FRAND" seperti di Uni Eropa. Dengan demikian, di Amerika Serikat, yang ditekankan adalah komitmen untuk memberikan lisensi dengan persyaratan yang "masuk akal"“ (reasonable), dan tidak harus fair. Namun demikan, dalam perkembangannya saat ini kedua terminologi tersebut dapat saling dipertukarkan penggunaannya. ${ }^{29}$

Istilah "firm commitment" mengacu pada kekuatan komitmen yang berlaku mengikat bagi pihak yang menyatakannya dan oleh karenanya, menimbulkan hak bagi pihak lain kepada siapa komitmen tersebut dinyatakan, untuk diimplementasikan. Dalam praktik, meskipun komitmen tersebut telah disampaikan dan berkekuatan mengikat, dapat muncul persoalan yang disebabkan oleh tidak adanya ukuran untuk menentukan apa yang dimaksud dengan "fair", "reasonable", dan "non-discriminatory". Demikian pula, terdapat kesulitan untuk menentukan batasan telah terjadinya pelanggaran komitmen FRAND dalam dugaan penyalahgunaan SEP. 30

Untuk mengatasi persoalan tersebut, timbul gagasan untuk dapat dimuatnya tingkat royalti (royalty rate) dalam komitmen FRAND. Namun demikian, gagasan tersebut mengandung kelemahan. Mario Mariniello dalam analisisnya menjelaskan bahwa penentuan tingkat royalti secara ex-ante tidak selalu dapat dilakukan, karena pemegang paten pada saat menyatakan komitmen FRAND-nya bisa jadi bahkan tidak mengetahui nilai sesungguhnya dari teknologinya yang diterima menjadi standard tersebut. Sebagai akibatnya, pemegang paten dipaksa untuk berkomitmen pada tingkat royalti yang secara ex-post ternyata tidak efisien dan berdampak pada pilihan yang tidak efisien. Dampak yang dapat terjadi berikutnya adalah pengambilan pilihan standard yang tidak efisien secara ex-ante. ${ }^{31}$

Hal lain yang membuat persoalan di atas lebih kompleks adalah bahwa dalam praktik dapat terjadi bahwa sengketa mengenai komitmen FRAND digantungkan pada pertanyaan mengenai validitas paten. Hal ini menimbulkan pertanyaan apakah SSO juga harus melakukan pemeriksaan terhadap validitas paten sebelum menerima suatu teknologi sebagai standard. ${ }^{32}$

\section{B. Beberapa Kasus Penyalahgunaan SEP di Uni Eropa}

\section{Kasus Rambus}

Dalam kasus Rambus, ${ }^{33}$ otoriatas persaingan usaha Uni Eropa berhadapan

29 Ibid., dalam bagian footnote no. 28.

30 Mario Mariniello. "Fair, Reasonable and Non-Discriminatory (FRAND) Terms: A Challenge for Competition Authorities", Journal of Competition Law and Economics Vol. 7, No. 3, (2011): 524-525.

31 Ibid..

32 Richard A. Epstein and David J. Kappos, “Legal Remedies for Patent Infringement: from General Principles to FRAND Obligations for Standard Essential Patents", Compeition Policy International Vol. 9, No. 2, (Autumn 2013): 81.

33 Rambus (Case COMP/38.636); DC Rambus v. FTC 24 November 2008. 
dengan perilaku anti persaingan yang menggunakan strategi 'patent ambush',34 'patent hold up', ${ }^{35}$ atau 'snake-in-the-grass'. ${ }^{36}$ Kasus Rambus menunjukkan jenis tertentu dari perilaku anti persaingan dari pelaku usaha dalam tahap pra-standar dalam rangka membangun dominasi di pasar post-standar melalui HKI dengan cara penyalahgunaan hak paten, dalam hal ini penyalahgunaan Standard Essential Patent (SEP).

Penyalahgunaan SEP merupakan kasus tipikal dalam sektor ITE dan farmasi. Kasus Rambus diilustrasikan di sini untuk menunjukkan masalah hukum yang mungkin timbul dalam standardisasi dari perspektif HKI dan hukum persaingan usaha dengan membandingkan pendekatan penyelesaian kasus tersebut di Amerika Serikan dan di Uni Eropa.

Rambus adalah perusahaan solusi teknologi inovatif yang didirikan di California, Amerika Serikat, yang memproduksi dan melisensikan teknologinya kepada perusahaan lain. The US Federal Trade Commission (selanjutnya, FTC) menuduh Rambus telah tidak mengungkapkan paten dan aplikasi paten yang memuat desain yang sedang dievaluasi untuk pembentukan standar untuk chip memori komputer oleh the Joint Electron Device Engineering Council (JEDEC). Tuduhan ini juga menyangkut perubahan yang dibuat Rambus pada permohonan patent pendingnya. Tujuan dari perubahan tersebut disinyalir untuk memastikan bahwa paten yang nanti akan dirilis sedapat mungkin menyamai fitur standar baru yang akan disepakati.

FTC menyatakan bahwa seandainya Rambus mengungkapkan rencana patennya, JEDEC dapat memiliki dua alternative untuk dieprtimbangkan: pertama, teknologi lain dapat digunakan dalam standar bukannya Rambus, atau kedua, menysaratkan Rambus untuk menyepakati komitmen FRAND (fair, wajar, dan non diskriminatif) sebelum memutuskan untuk memilih standar dengan teknologi Rambus.

FTC berpendapat bahwa Rambus sengaja tidak mengungkapkan kebijakan patennya untuk memikat anggota lain dalam JEDEC sebagai standard setting organization (SSO), sehingga mereka tidak akan memperhitungkan bahwa Rambus sebenarnya sedang menyesuaikan paten yang relevan untuk teknologinya. Oleh karena mereka tidak memiliki informasi yang cukup untuk mengevaluasi dan memilih teknologi berkaitan dengan biaya aktual untuk menggunakan teknologi tersebut, mereka telah disesatkan untuk teknologi Rambus. Akibatnya, mengadopsi teknologi Rambus dalam standar memberi kekuatan monopoli Rambus di pasar teknologi. ${ }^{37}$

34 Josef Drexl, op.cit.: 531-532; Daniel Culley, et.al., "Learning from Rambus How to Tame those Troublesome Trolls", The Antitrust Bulletin, Vol. 57, N.o. 1, (2012): 128-129.

35 Culley, ibid., p.121-122.

36 Robert P. Merges \& Jeffery M. Kuhn, “An Estoppel Doctrine for Patented Standards”, California Law Review, Vo. 97, No. 1, (2009): 13.

37 DC Rambus v. FTC 24 November 2008, 3. 
Namun demikian, dalam putusan bandingnya, D.C. Court menolak argumen FTC karena dua alasan: pertama, FTC tidak bisa membuktikan bahwa tanpa perilaku menyesatkan Rambus, akan ada teknologi alternatif yang dipilih oleh SSO. Kedua, harga yang lebih tinggi dari yang diperkirakan karena biaya lisensi yang dikenakan oleh Rambus justru akan cenderung menarik pesaing baru yang bisa menawarkan harga lebih rendah dari Rambus dan bukannya menghambat persaingan. ${ }^{38}$

Keputusan banding tersebut tampaknya tidak memperhitungkan terciptanya 'lockin' bagi pengguna teknologi seketika standar berlaku, sehingga menjadi tidak mungkin bagi pesaing potensial untuk masuk ke dalam pasar. Masalah lock-in pengguna teknologi tersebut timbul dari switching cost yang tinggi karena sunk cost dari investasi yang telah dibuat untuk mengadopsi teknologi yang menjadi standar. Rambus dengan perilaku curangnya telah menyesatkan anggota JEDEC lainnya untuk berinvestasi dalam teknologi yang baru. ${ }^{39}$

Kasus ini menunjukkan apa yang disebut dengan persaingan untuk membentuk pasar, dan bukan persaingan di dalam pasar seperti yang sudah lazim dikenal. Pasar yang dipersaingkan oleh para pelaku usaha tersebut belum ada selama proses pembentukan standar. Dalam kasus ini terlihat bahwa perilaku curang dalam proses pembentukan standar dapat menciptakan hambatan masuk setelah pasar terbentuk, yaitu seketika teknologi yang bersangkutan diadopsi dalam standar.

Di Uni Eropa, European Commission menerapkan pendekatan yang berbeda untuk kasus Rambus didasarkan pada dugaan penyalahgunaan posisi dominan yang merupakan pelanggaran Pasal 102 TFEU. Namun demikian, Komisi harus berurusan dengan masalah yang timul karena Pasal 102 TFEU hanya melarang penyalahgunaan posisi dominan dan bukan upaya untuk memonopoli melalui perilaku curang yang menyesatkan. Rambus sebelum adopsi teknologi dalam standar adalah bukanlah perusahaan yang dominan dan memperoleh dominasinya setelah teknologinya diadopsi menjadi standar meskipun dengan cara yang curang. ${ }^{40}$

Oleh karena kompleksitas ini, Komisi mendasarkan argumentasinya pada harga yang berlebihan (excessive pricing) untuk lisensi yang dikenakan oleh Rambus, yang tidak akan mungkin dikenakan seandainya Rambus tidak menyesatkan anggota lain untuk mengadopsi teknologi dalam standar (patent ambush). Untuk menanggapi tuduhan tersebut, Rambus menawarkan komitmen yang di dalamnya menyepakati untuk menurunkan biaya royaltinya. Komitmen itu kemudian diterima oleh Komisi. ${ }^{41}$

38 Drexl, loc.cit; Joel M. Wallace, "Rambus v. F.T.C. in the Context of Standard-Setting Organizations, Antitrust, and the Patent Hold-Up Problem”, Berkley Technology Law Journal Vol. 24, (2009): 687; Culley, op.cit.: 125.

39 Perilaku semacam ini sering disebut juga 'sunk-cost opportunism'. Lihat Culley, ibid., p.139.

40 Lihat Drexl, op.cit.: 533.

41 Drexl, ibid.: 533; Culley, op.cit.: 128-129. 


\section{Kasus Motorola}

Pada tanggal 29 April 2014, European Commission mengeluarkan keputusan yang disebut sebagai 'prohibition decision'. Keputusan tersebut menyatakan bahwa penyalahgunaan SEP Motorola smartphone dengan meminta injunctive relief, dengan mempertimbangkan situasi khusus penggunaan injunctive relief tersebut, merupakan suatu pelanggaran terhadap larangan untuk menyalahgunakan posisi dominan di bawah Pasal 102 TFEU. ${ }^{42}$

Kasus ini dimulai dengan keluhan Apple pada tahun 2012 dengan memohon intervensi Komisi dalam kasus gugatan SEP oleh Motorola terhadap Apple di hadapan Mannheim Regional Court di Jerman, yang di dalamnya Motorola mengajukan permohonan injunctive reliefatas dasar tuduhan pelanggaran paten yang menurut Motorola telah dilakukan oleh Apple.

Kasus Motorola v. Apel di Pengadilan Jerman mempersoalkan penentuan besaran royalti untuk penggunaan standard GPRS dari European Telecommunications Standaridisation Institute (ETSI), bagian dari standar GSM, yang merupakan standar industri kunci untuk komunikasi mobile dan nirkabel. Dalam proses adopsi standar, Motorola telah berkomitmen untuk memberikan lisensi paten yang dinyatakan sebagai standard yang esensial kepada pihak lain dalam klausula yang disebut dengan klausula fair, reasonable and non-discrimintaion (FRAND). Klausula FRAND merupakan klausula yang lazim diintegrasikan dalam kesepakatan ketika suatu teknologi diadopsi menjadi standard untuk memastikan dihindarkannya penyalahgunaan SEP oleh pemegangnya.

Namun demikian, komitmen untuk memberikan lisensi itu sendiri bukanlah merupakan kata sepakat untuk pemberian lisensi, melainkan hanya kesanggupan bahwa lisensi nantinya akan diberikan. Lisensi baru akan diberikan dalam praktiknya jika sudah disepakati persyaratannya secara individual di antara para pihak, salah satunya mengenai besarnya royalti.

Pada tahun 2012, Motorola menyetujui tawaran Apple untuk mengambil lisensi dari SEP GPRS sesuai dengan apa yang disebut sebagai Orange-Book-Standard Jerman yang memuat daftar mengenai kesepatakankesepakatan lisensi. Namun demikian, tarif royalti tidak ditentukan dan sebagai gantinya, mereka hanya menyepakati bagaimana nilai royalti akan ditentukan, yaitu menurut 'kebijaksanaan sesuai dengan keadilan dan sesuai dengan standar FRAND dalam industri'. Klausula menurut 'kebijaksanaan sesuai dengan keadilan' dalam hukum Jerman dapat ditinjau dan ditentukan oleh pengadilan, ketika para pihak tidak bersepakat.

Dalam kasus ini, Apple tidak setuju dengan royalti sebesar $2,25 \%$ yang ditawarkan oleh Motorola dan mengatakan 
bahwa nilai tersebut bukan nilai yang adil, masuk akal, dan non-diskriminatif. ${ }^{43}$ Selain itu, Apple mengajukan counter claim bahwa beberapa klausula perjanjian lisensi tidak dapat dilaksanakan. Hal ini mengakibatkan ancaman dilarangnya penjualan terhadap produk Apple seperti iPhone dan iPads menggunakan koneksi 3G di Jerman. ${ }^{44}$ Untuk menanggapi hal tersebut, Apple meminta European Commission untuk campur tangan dalam kasus ini dan pengadilan Jerman menyatakan bahwa proses litigasi ditunda menunggu hasil proses hukum persaingan uasha di Uni Eropa. ${ }^{45}$

Ada dua poin utama dalam keputusan European Commission berkaitan denganunsurunsur anti persaingan. Pertama, berkaitan dengan situasi spesifik untuk mendapatkan perintahinjunctiverelief-lazimnyamerupakan perintah untuk menghentikan perbuatan yang dinyatakan sebagai pelanggaran, Komisi menyatakan bahwa 'upaya untuk memperolah perintah injunctive relief atas dasar SEP dapat terjadi merupakan penyalahgunaan posisi dominan jika pemegang SEP telah memberikan komitmen sukarela untuk melisensikan SEPnya berdasarkan prinsip FRAND dan ketika perusahaan terhadap yang perintah tersebut ditujukan dengan sukarela bersedia menyepakati perjanjian lisensi berdasarkan prinsip FRAND tersebut' Komisi membedakan tindakan tersebut dari pencarian dari upaya untuk mendapatkan perintah injunctive relief secara umum yang merupakan prosedur yang sah dalam hal terjadi pelanggaran paten.

Fakta bahwa Apple menawarkan perjanjian lisensi untuk SEP GPRS sesuai dengan Orange-Book-Standard Jerman jelas menunjukkan kesediaan Apple untuk masuk ke dalam perjanjian lisensi sesuai dengan prinsip FRAND. Efek anti persaingan dari upaya mendapatkan perintah injunctive relief yang dilakukan oleh Motorola adalah dikeluarkannya produk-produk dari perusahaan yang telah bersedia untuk memasuki kesepakatan lisensi tersebut dari pasar. Risiko tersebut akan berpotensi membahayakan proses negosiasi dan mengarah pada kesepakatan atas persyaratan lisensi oleh calon pemegang lisensi, yang mustinya tidak akan disepakatinya jika

43 Marc Kessler, "Apple-Patentstreit: Motorola Fordert 2,25 Prozent Umsatzbeteiligung", Teltarif (6 February 2012), http://www.teltarif.de/apple-motorola-patentstreit-lizenz-gebuehr-2-25-prozent-forderung-frand/ news/45578.html, diakses 3 Juli 2018.

44 Joachim Jahn, "Gericht Bremst Vertrieb von Apple-Produkten“, Frankfurter Allgemeine (3 Februari 2012), http://www.faz.net/aktuell/technik-motor/patentstreit-mit-motorola-gericht-bremst-vertrieb-von-appleprodukten-11636311.html, diakses 3 Juli 2018; Simon Fistrich, "Motorola vs. Apple: iPhone 3G und iPad Zeitweise Aus Apples Online-Store Verschwunden“, PC Games (6 Februari 2012), http://www.pcgames.de/ Motorola-Firma-18761/GNews/Motorola-vs-Apple-iPhone-3G-und-iPad-zeitweise-aus-Apples-Online-Storeverschwunden-866789/, diakses 3 Juli 2018; Alexander Kuch, "Dritte Motorola-Patentklage Gegen Apple in Mannheim Abgewiesen“, Teltarif (10 Februari 2012), http://www.teltarif.de/apple-motorola-patentsreitlandgericht-mannheim/news/45635.html, diakses 3 Juli 2018

45 Sikap Pengadilan Jerman tersebut selaras dengan Council Regulation (EC) 1/2003 of 16 December 2002 on the implementation of the rules on competition laid down in Articles 81 and 82 of the Treaty [2003] OJ L1/1 Art. 16. 
risiko tersebut tidak ada. Komisi lebih lanjut mengacu pada kerugian terhadap inovasi dan kesejahteraan konsumen sebagai hasil dari praktik semacam itu.

Kedua, Komisi juga menyatakan bahwa calon pemegang lisensi yang secara sukarela sudah bersedia memasuki kesepakatan lisensi tersebut harus tetap memiliki hak untuk mempersoalkan keabsahan dan tidak adanya pelanggaran SEP. Dengan adanya ancaman akan dikenakannya injunctive relief, calon pemegang lisensi akan beraada di bawah tekanan untuk menyerahkan hak-hak mereka tersebut. Menghapuskan hak tersebut dari calon pemegang lisensi semacam itu, yang pada dasarnya merupakan pihak yang akan mengimplementasikan standard, akan memaksa mereka dan pada akhirnya konsumen untuk membayar SEP yang tidak valid dan tidak dilanggar.

\section{Kasus Samsung}

Pada tanggal 29 April 2014, Komisi menerima komitmen yang ditawarkan oleh Samsung yang mengikat secara hukum, bahwa Samsung tidak akan menempuh upaya untuk mendapatkan perintah injunctive relief di Eropa berdasarkan SEP untuk smartphone dan tablet terhadap pemegang lisensi dari framework tertentu, yang di dalamnya memuat klausula bahwa setiap sengketa mengenai persyaratan FRAND akan diselesaikan oleh pengadilan atau, berdasarkan kesepakatan antara para pihak, oleh seorang arbiter. ${ }^{46}$

Berbeda dari keputusan larangan (prohibition decision) ${ }^{47}$ dalam kasus Samsung, Komisi dalam kasus Motorola mengambil langkah yang berbeda untuk memecahkan kasus ini dengan mengambil keputusan dalam bentuk komitmen (commitment decision), ${ }^{48}$ yang di dalamnya Komisi menerima komitmen yang secara sukarela ditawarkan oleh Samsung yang telah dianggap sebagai tanggapan yang tepat untuk menyelesaikan persoalan. ${ }^{49}$ Kasus ini dimulai sendiri oleh Komisi dan bukan atas dasar adanya laporan atau keluhan.

Komitmen Samsung mencakup baik lisensi unilateral maupun lisensi silang. Lisensi unilateral dalam komitmen mengacu pada perjanjian lisensi untuk SEP telepon seluler elektronik untuk peralatan telepon seluler, sejauh itu belum berlisensi. Lisensi silang mengacu pada perjanjian timbal balik lisensi untuk SEP telepon seluler elektronik untuk peralatan telepon seluler dan SEP telepon seluler tertentu yang potensial yang dicakup dengan prinsip resiprositas.

Kecuali didefinisikan sebaliknya dalam FRAND dari suatu SSO yang berkomitmen atas FRAND yang telah dibuat, timbal balik berarti ,membuat tawaran untuk melisensikan SEP telepon seluler berdasarkan FRAND

46 Samsung (Case AT.39939) Commission Decision 2014/C 350/08 [2014] OJ 350/8.

47 Council Regulation (EC) 1/2003 Art. 7.

48 Ibid., Art. 9.

49 Commission (EC), 'To Commit or Not to Commit: Deciding between Prohibition and Commitments' (Policy Brief, March 2014) diakses 4 Juli $2018<$ http://ec.europa.eu/competition/publications/cpb/2014/003_en.pdf>. 
dengan tunduk pada persyaratan bahwa pihak lawan berjanji akan bertimbal balik memberikan lisensi berkaitan dengan SEP yang digunakan pada telepon seluler yang sama berdasarkan syarat dan kondisi yang konsisten dengan komitmen FRAND yang mencakup paten tersebut ${ }^{6} .{ }^{50}$

\section{SEP dan Hukum Persaingan Usaha di Indonesia}

\section{Rujukan terhadap Hukum Persaingan Usaha dalam Undang- undang No. 13 Tahun 2016 tentang Paten}

Rujukan terhadap hukum persaingan usaha dalam Undang-undang No. 13 Tahun 2016 tentang Paten (selanjutnya disebut UU Paten) dapat ditemukan dalam ketentuan yang mengatur tentang lisensi wajib. Pasal 100 huruf b UU Paten mengatur bahwa:

"Dalam hal Lisensi-wajib terkait dengan teknologi semi konduktor, penerima Lisensi-wajib hanya dapat menggunakan Lisensi-wajib dimaksud untuk ... melaksanakan tindakan yang ditentukan berdasarkan putusan pengadilan atau keputusan lembaga terkait yang menyatakan bahwa pelaksanaan Paten dimaksud merupakan tindakan monopoli atau persaingan usaha tidak sehat."

Dalam Penjelasan Pasal tersebut dinyatakan bahwa:

"Yang dimaksud dengan "lembaga terkait" adalah lembaga yang dibentuk dan bertugas untuk mengawasi persaingan usaha sebagaimana diatur dalam peraturan perundang-undangan."

Berdasarkan peraturan perundangundangan yang berlaku saat ini, Undangundang No. 5 Tahun 1999 tentang Larangan Praktik Monopoli dan Persaingan Usaha Tidak Sehat (selanjutnya disebut UU Persaingan Usaha) Pasal 30 ayat (1), maka ,lembaga terkait“ yang dimaksud adalah Komisi Pengawas Persaingan Usaha (KPPU).

Rujukan terhadap hukum persaingan usaha dalam UU Paten dengan demikian hanya secara spesifik disebutkan dalam ketentuan mengenai lisensi wajib untuk teknologi semi konduktor dan tidak disebutkan dalam teknologi yang lain. Jika dibandingkan, rujukan dalam Undang-undang No. 28 Tahun 2014 tentang Hak Cipta (selanjutnya disebut UU Hak Cipta) memuat rujukan terhadap hukum persaingan usaha secara lebih umum daripada rujukan dalam Pasal 100 huruf b UU Paten. Pasal 82 UU Hak Cipta mengatur:

$\begin{array}{lrr}\text { “(1) Perjanjian } & \begin{array}{r}\text { Lisensi } \\ \text { dilarang }\end{array} \text { memuat } & \text { ketentuan } \\ \text { yang mengakibatkan } & \text { kerugian } \\ \text { perekonomian Indonesia. } & \end{array}$

(2) Isi perjanjian Lisensi dilarang bertentangan dengan ketentuan peraturan perundang-undangan.

(3) Perjanjian Lisensi dilarang menjadi saranauntuk menghilangkan atau mengambil alih seluruh hak Pencipta atas Ciptaannya." 
Dalam bagian Penjelasan, Pasal 82 ayat (2) UU Hak Cipta tersebut dijelaskan sebagai berikut:

"Yang dimaksud dengan ,ketentuan peraturan perundang-undangan“" antara lain Kitab Undang-Undang Hukum Perdata dan UndangUndang yang mengatur mengenai larangan praktek monopoli dan persaingan usaha tidak sehat."

Dengan demikian, rujukan terhadaphukum persaingan usaha secara eksplisit tercantum dalam bagian Penjelasan Pasal 82 ayat (2). Lebih lanjut dijelaskan bahwa pengaturan tersebut ditujukan untuk memberikan perlindungan kepada Pencipta, Pemegang Hak Cipta, atau pemilik Hak Terkait. ${ }^{51}$

Jika dalam UU Paten rujukan terhadap hukum persaingan usaha dibuat dalam konteks lisensi wajib dan lebih spesifik lagi dalam teknologi semi konduktor, dalam UU Hak Cipta rujukan dibuat dalam konteks isi perjanjian lisensi secara umum. Pengaturan mengenai perjanjian lisensi dalam paten berdasarkan Pasal 78 UU Paten diatur sebagai berikut:

"Perjanjian Lisensi dilarang memuat
ketentuan yang dapat merugikan
kepentingan nasional Indonesia
atau memuat pembatasan yang
menghambat kemampuan bangsa
Indonesia dalam melakukan
pengalihan, penguasaan, dan
pengembangan teknologi."

Dengan demikian, ketentuan mengenai perjanjian lisensi dalam paten adalah sama dengan dalam hak cipta, minus bagian yang memuat ketentuan bahwa „Isi perjanjian Lisensi dilarang bertentangan dengan ketentuan peraturan perundang-undangan“.

\section{Pengecualian dalam Pasal 50 huruf b Undang-undang No. 5 Tahun 1999 tentang Larangan Praktik Monopoli dan Persaingan Usaha Tidak Sehat}

Perlindungan paten dalam hukum nasional Indonesia baru-baru ini diperbarui dengan diberlakukannya UU No. 13 Tahun 2016 tentang Paten. Namun demikian, perlindungan paten dalam hal SEP sebagaimana dalam pengaturan paten secara universal, tidak terdapat kekhususan dalam perlindungan paten untuk SEP. Kekhasan SEP adalah pada persoalan lisensi dan kaitannya dengan potensi penyalahgunaan hak paten.

UU No. 5 Tahun 1999 mengecualikan berlakunya undang-undang tersebut dalam perjanjian yang berkaitan dengan "berkaitan dengan hak atas kekayaan intelektual seperti lisensi, paten, merek dagang, hak cipta, desain produk industri, rangkaian elektronik terpadu, dan rahasia dagang, serta perjanjian yang berkaitan dengan waralaba" dalam Pasal 50 huruf $b$.

Pengecualian tersebut tidak dimaksudkan untuk menyatakan bahwa hukum persaingan usaha dan HKI merupakan dua hal yang saling bertolak belakang. Dapat diinterpretasikan 
sebagai penegasan bahwa perbuatan curang dalam dunia usaha sepanjang dilakukan dengan cara melanggar HKI maka tunduk pada rezim tersendiri dan karenanya penegakannya tidak melalui penegakan hukum persaingan usaha.

HKI dan hukum persaingan usaha berbagi fungsi yang sama dalam hal mendorong dan melindungi insentif untuk berinovasi, meskipun memiliki fokus yang berbeda. Jika HKI memusatkan perhatiannya pada perlindungan atas karya intelektual, maka hukum persaingan usaha memiliki fokus pada jaminan persaingan usaha yang sehat dan perlindungan dari distorsi pasar.

Walaupun demikian, pengecualian dalam Pasal 50 huruf b UU No. 5 Tahun 1999 tersebut telah dirumuskan terlalu ketat sehingga tidak memberi ruang untuk berfungsinya UU No. 5 Tahun 1999 dalam kasus-kasus penyalahgunaan $\mathrm{HKI},{ }^{52}$ termasuk di dalamnya paten. Dalam konteks tersebut, disusunlah Peraturan Komisi Pengawas Persaingan Usaha No. 2 Tahun 2009 tentang Pedoman Pengecualian Penerapan UU No 5 1999 Berkaitan Dengan Hak Atas Kekayaan Intelektual (selanjutya disebut Perkom 2/2009), yang walaupun memiliki lingkup berlaku terbatas yaitu sebatas internal dalam lingkungan KPPU, namun setidaknya memberikan pencerahan mengenai bagaimana pengacualian tersebut di atas diinterpretasikan di dalam implementasi UU No. 5 Tahun 1999 oleh KPPU.

\section{Peraturan Komisi Pengawas Persaingan Usaha No. 2 Tahun 2009 tentang Pedoman Pengecualian Penerapan UU No 5 1999 Berkaitan dengan Hak Atas Kekayaan Intelektual}

Hal yang penting untuk dipahami adalah konsep mendasar bahwa dengan dimilikinya HKI, tidak berarti dengan sendirinya dikuasainya posisi monopoli. Konsep hak eksklusif dalam HKI oleh karenanya perlu dipahami sebagai hal yang berbeda dari pengertian monopoli dalam hukum persaingan usaha.

Jika pengertian hak eksklusif dalam HKI mengandung pengertian monopoli dalam arti bahwa tidak ada pihak lain yang memiliki hak yang sama dengan pemegang HKI untuk obyek HKI yang sama, maka pengertian monopoli dalam hukum persaingan uasha adalah dikuasainya pasar oleh suatu pelaku usaha. Pasal 1 angka 1 UU No. 5 Tahun 1999 mendefinisikan monopoli sebagai "penguasaan atas produksi dan atau pemasaran barang dan atau atas penggunaan jasa tertentu oleh satu pelaku usaha atau satu kelompok pelaku usaha."

Selain itu, dengan memegang HKI, tidak berarti telah terjadi praktik monopoli dalam konteks hukum persaingan usaha. Pasal UU No. 5 Tahun 1999 mendefinisikan praktik monopli sebagai "pemusatan kekuatan ekonomi oleh satu atau lebih pelaku usaha 
yang mengakibatkan dikuasainya produksi dan atau pemasaran atas barang dan atau jasa tertentu sehingga menimbulkan persaingan usaha tidak sehat dan dapat merugikan kepentingan umum."

Namun demikian, dapat terjadi intervensi hukum persaingan usaha menjadi diperlukan ketika HKI disalahgunakan, dengan kata lain dalam konteks Pasal 50 huruf b UU No. 5 Tahun 1999, jika lisensi dieksplotiasi dengan tujuan atau berakibat terjadinya praktik monopoli dan/atau persaingan usaha tidak sehat.

Perkom No. 2/2009 menjelaskan lebih lanjut tiga alternatif konstelasi yang mungkin terjadi: (1) pemegang HKI merupakan satusatunya pelakuusaha dalampasarbersangkutan atau menunjuk hanya satu pemegan lisensi; (2) penguasaan produksi dan/atau pemasaran karena dipegang hanya oleh pemegang HKI atau pemegang lisensinya; (3) kegiatan usaha pemegang HKI atau lisensinya dilakukan secara curang; atau (4) kegiatan usaha pemegang HKI atau lisensinya merugikan kepentingan orang banyak. ${ }^{53}$ Jika dicermati, perumusan alternatif tersebut terlalu umum dan tidak secara spesifik mngklarifikasi bagaimana penyalahgunaan HKI dapat terjadi dan menjadi kompetensi hukum persaingan usaha untuk menanganinya.

Berkaitan dengan paten, Perkom No. 2/2009 menjelaskan prosedur analisis untuk mengevaluasi kasus-kasus penyalahgunaan paten. Pertama-tama, dalam kasus penolakan lisensi, perlu dianalisis apakah teknologi yang dimintakan lisensinya merupakan essential facility atau bukan. Hanya jika ya, maka hukum persaingan usaha dapat melakukan intervensi dan dalam hal terbukti adanya pelanggaran terhadap UU No. 5 Tahun 1999, maka dapat dikenakan apa yang disebut dengan lisensi wajib (mandatory licensing).

Kedua, dalam kasus-kasus lisensi yang menyangkut perjanjian lisensi yang membatasi dalam bentuk exclusive dealing, dari sejumlah tipe lisensi yang disebut di dalam Perkom tersebut, ada dua jenis yang perlu mendapatkan perhatian khusus berkaitan dengan lisensi paten, yaitu (1) pool licensing dan crosslicensing dan (2) grant back licensing. Dalam hal pertama, lisensi masih dimungkinkan jika bertujuan atau berakibat pada tercapainya atau peningkatan efisiensi. Hanya dalam hal terjadi penguasaan lisensi yang menimbulkan posisi dominan, maka perlu dianalisis lebih lanjut apakah dalam struktur pasar demikian, para pelaku usaha masih dapat bersaing secara efektif.

Dalam hal kedua, dimasukkannya klausula grant back dengan sendirinya memberikan landasan atau justifikasi untuk intervensi hukum persaingan usaha, karena grant back licensing pada dasarnya sudah merupakan pembatasan bagi pelaku usaha dengan menghilangkan peluang untuk menjadi yang terdepan dalam persaingan. Dengan kata

53 Peraturan Komisi Pengawas Persaingan Usaha No. 2 Tahun 2009 tentang Pedoman Pengecualian Penerapan UU No 51999 Berkaitan Dengan Hak Atas Kekayaan Intelektual, hlm. 7. 
lain, grant back licensing pada prinsipnya berpotensi untuk menghilangkan persaingan.

\section{Simpulan}

Dari paparan dan analisis dalam sub-sub bab di atas, dapat ditarik kesimpulan sebagai berikut:

Pertama, penyalahgunaan SEP dapat menjadi persoalan hukum persaingan usaha di Uni Eropa dalam sejumlah hal: (1) penentuan pasar bersangkutan dalam hal proses adopsi SEP merupakan persaingan untuk membentuk pasar yang baru; (2) definisi posisi dominan dalam hal SEP belum diadopsi namun perbuatan curang telah dilakukan dan merugikan; (3) penghapusan sejumlah klausula lisensi dalam pengecualian berlakunya hukum persaingan, karena ptensi dampak negatifnya terhadap persaingan, seperti cross-licensing, exclusice grant-back, klausula non-challenge dalam kesepakatan penyelesaian sengketa; (4) dampak penyalahgunaan paten terhadap persaingan intra-technology; dan (5) pertimbangan munculnya disruptive innovation dalam kasus SEP dan metode analisis hukum persaingan yang tepat.

Kedua, tiga kasus dibahas dalam paper ini, yaitu kasus Rambus, kasus Motorola, dan kasus Samsung. Ketiga kasus tersebut menunjukkan beberapa persoalan hukum persaingan yang dapat timbul dalam kasus penyalahgunaan SEP.

Kasus Rambus menunjukkan adanya persaingan untuk membentuk pasar, dan bukan persaingan di dalam pasar seperti yang sudah lazim dikenal. Perilaku curang dalam proses pembentukan standar dapat menciptakan hambatan masuk setelah pasar terbentuk, yaitu seketika teknologi yang bersangkutan diadopsi dalam standar. Kesulitannya adalah bahwa pada saat perbuatan curang tersebut dilakukan, belum terbentuk posisi dominan, sehingga sulit untuk dikategorikan sebagai penyalahgunaan posisi dominan. Dalam keputusannya, Komisi Persaingan Uni Eropa mendasarkan argumentasinya pada harga yang berlebihan (excessive pricing) untuk lisensi yang dikenakan oleh Rambus, yang tidak akan mungkin dikenakan seandainya Rambus tidak menyesatkan anggota lain untuk mengadopsi teknologi dalam standar (patent ambush).

Dalam kasus Motorola, persoalan yang muncul adalah penentuan besaran royalti untuk penggunaan standard. Teradapat dua hal penting dari keputusan Komisi Persaingan Uni Eropa dalam kasus ini, yaitu bahwa (1) bahwa 'upaya untuk memperolah perintah injunctive relief atas dasar SEP dapat terjadi merupakan penyalahgunaan posisi dominan jika pemegang SEP telah memberikan komitmen sukarela untuk melisensikan SEPnya berdasarkan prinsip FRAND dan ketika perusahaan terhadap yang perintah tersebut ditujukan dengan sukarela bersedia menyepakati perjanjian lisensi berdasarkan prinsip FRAND tersebut'. Ini harus dibedakan dari prosedur umum injunctive relief yang sah. (2) Calon pemegang lisensi yang secara sukarela sudahbersediamemasukikesepakatan 
lisensi tersebut harus tetap memiliki hak untuk mempersoalkan keabsahan dan tidak adanya pelanggaran SEP.

Dalam kasus Samsung, Komisi Persaingan Uni Eropa menerima komitmen Samsung yang memuat lisensi unilateral dan lisensi silang yang didasarkan pada prinsip resiporasitas atau timbal balik.

Ketiga, intervensi hukum persaingan Indonesia dalam kasus penyalahgunaan SEP belum sampai pada kasus riil yang ditangani oleh KPPU, namun secara konseptual sudah diakui dan diakomodasi dalam Perkom No. 2/2009 antara lain dengan memuat prosedur analisis untuk mengevealuasi kasus penyalahgunaan HKI. Sebagai contoh adalah penggunaan facility doctrine dalam analisis atas kasus penolakan atas lisensi dan serangkaian tes dalam kasus exclusive dealing, dengan memusatkan perhatian pada pool/cross-licensing dan grant-back licensing.

\section{DAFTAR PUSTAKA}

\section{Buku}

Hansen, Knud, et.al. (eds.), Undang-Undang

Larangan Praktek Monopoli dan

Persaingan Usaha Tidak Sehat (Jakarta:

Katalis, 2002).

\section{Jurnal}

Contreras, Jorge L., "Fixing FRAND: A Pseudo-Pool Approach to StandardBased Patent Licensing", Antitrust Law Journal Vol. 49, (2013): 47-97.

Cotter, Thomas F., "The Comparative Law and Economics of Standard-Essential Patents and FRAND Royalties", Texas Intellectual Property Law Journal Vol. 22, (2014): 311-363.

Culley, Daneil, et.al., "Learning from Rambus How to Tame those Troublesome Trolls" The Antitrust Bulletin Vol. 57, No. 1, (2012): 117-160.
Drexl, Josef, "Anti-Competitive Stumbling Stones on the Way to A Cleaner World: Protecting Competition in Innovation Without A Market", Journal of Competition Law \& Economics Vol. 8, No. 3, (2012): 507-542.

Encaoua, David and Hollander, Abrahamn, "Competition Policy and Innovation" Oxford Review of Economic Policy Vol. 18, No. 1, (2002): 63-79.

Epstein, Richard A.and Kappos, David J., "Legal Remedies for Patent Infringement: from General Principles to FRAND Obligations for Standard Essential Patents", Compeition Policy International Vol. 9, No. 2, (Autumn 2013): 60-89.

Hovenkamp, Herbert J., "Competition in Information Technologies: StandardEssential Patents, Non-Practicing 
Entities and FRAND Bidding”, DC Rambus v. FTC, 24 November 2008.

University of Iowa Legal Studies European Commission, "Patents and

Research Paper No. 12-32. (October 3, 2012): 1-20.

Mariniello, Mario, "Fair, Reasonable and Non-Discriminatory

(FRAND)

Terms: A Challenge for Competition Authorities", Journal of Competition Law and Economics Vol. 7, No. 3, (2011): 523-541.

Merges, Robert P., and Kuhn Jeffery M., "An Estoppel Doctrine for Patented Standards", California Law Review, Vo. 97, No. 1, (2009): 1-50.

Michael L. Katz and Carl Saphiro, 'Systems Competition and Network Effects', Journal of Economic Perspectives Vol. 8, No. 2 (Spring 1994): 93-115.

Wallace, Joel. M., "Rambus v. F.T.C. in the Context of Standard-Setting Organizations, Antitrust, and the Patent Hold-Up Problem”, Berkley Technology Law Journal Vol. 24, (2009): 661-693.

Weber, Rolf H., "Competition Lawversus FRAND Terms in IT Markets", World Competition 34, no. 1 (2011): 51-71.

\section{Naskah Internet}

Commission (EC), 'To Commit or Not to Commit: Deciding between Prohibition and Commitments'(Policy Brief, March 2014), http://ec.europa.eu/competition/ publications/cpb/2014/003 en.pdf, diakses 4 Juli 2018.
Standards: A Modern Framework for IP-Base Standardization" (Final Report, 25 March 2014), http://ec.europa. eu/DocsRoom/documents/4843/ attachments/1/translations/en/ renditions/pdf, diakses 6 Juli 2018.

Fistrich, Simon, "Motorola vs. Apple: iPhone 3G und iPad Zeitweise Aus Apples Online-Store Verschwunden“, $P C$ Games (6 Februari 2012), http://www. pcgames.de/Motorola-Firma-18761/ GNews/Motorola-vs-Apple-iPhone3G-und-iPad-zeitweise-aus-ApplesOnline-Store-verschwunden-866789/, diakses 3 Juli 2018.

Jahn, Joachim, "Gericht Bremst Vertrieb von Apple-Produkten“, Frankfurter Allgemeine (3 Februari 2012), http://www.faz.net/aktuell/technikmotor/patentstreit-mit-motorolagericht-bremst-vertrieb-von-appleprodukten-11636311.html, diakses 3 Juli 2018 .

Kuch, Alexander "Dritte MotorolaPatentklage gegen Apple in Mannheim abgewiesen“, Teltarif (10 Februari 2012), http://www.teltarif.de/applemotorola-patentsreit-landgerichtmannheim/news/45635.html, diakses 3 Juli 2018.

Marc Kessler, “Apple-Patentstreit: 
Motorola Fordert 2,25 Prozent Umsatzbeteiligung“, $\quad$ Teltarif (6 February 2012), http://www.teltarif. de/apple-motorola-patentstreit-lizenzgebuehr-2-25-prozent-forderung-frand/ news/45578.html, diakses 3 Juli 2018.

Rambus (Case COMP/38.636).

\section{Peraturan Perundang-undangan}

Commission Regulation (EU) No 316/2014 of 21 March 2014 on the application of Article 101(3) of the Treaty on the Functioning of the European Union to categories of technology transfer agreements Text with EEA relevance' [2014] OJ 2014 L93/17.

Communication from the Commission (2011/C 11/01) of 14 January 2011 on 'Guidelines on the applicability of Article 101 of the Treaty on the Functioning of the European Union to horizontal co-operation agreements' [2011] OJ 2011 C11/1.

Communication from the Commission (2014/C 89/03) of 28 March 2014 on 'Guidelines on the application of Article 101 of the Treaty on the Functioning of the European Union to technology transfer agreements' [2014] OJ 2014 C89/3.

Council Regulation (EC) 1/2003 of 16 December2002 on theimplementation of the rules on competition laid down in Articles 81 and 82 of the Treaty [2003] OJ L1/1.

Motorola (Case AT.39985) Commission Decision 2014/C 344/06 [2014] OJ C344/6.

Peraturan Komisi Pengawas Persaingan Usaha No. 2 Tahun 2009 tentang Pedoman Pengecualian Penerapan UU No 51999 Berkaitan Dengan Hak Atas Kekayaan Intelektual.

Samsung (Case AT.39939) Commission Decision 2014/C 350/08 [2014] OJ $350 / 8$.

Undang-undang No. 5 Tahun 1999 tentang Larangan Praktik Monopoli dan Persaingan Usaha Tidak Sehat.

Undang-undang No. 28 Tahun 2014 tentang Hak Cipta.

Undang-undang No. 13 Tahun 2016 tentang Paten.

X/Open Group (Case IV/31.458) Commisssion Decision 87/69/EEC [1987] OJ L 35/36 